\title{
Pengaruh pendidikan kesehatan bagi ibu terhadap asupan energi, aktivitas fisik dan indeks massa tubuh pada anak kelebihan berat badan
}

\author{
Miratul Haya $^{1}$, Mexitalia Setiawati E ${ }^{2}$, Ani Margawati ${ }^{2}$
}

\begin{abstract}
Background: The percentage of overweight children in Bengkulu (16.4\%) is higher than the national (11.9\%). Factors causing overweight is a high energy intake and low physical activity.

Objective : To analyze the impact of health education for mothers in changes of maternal behavior, energy intake, physical activity level and Body Mass Index (BMI) z-score among overweight children 3-6 years old.

Methode : Quasi-Experiment with non-randomized pre-post test control group design. Subjects (48 mothers) were selected purposively and divided into 2 groups (treatment and control). Health education in the treatment group was conducted 6 times in 12 weeks. Analyses were conducted by Independent t-test, Mann Whitney, Paired t-test, Wilcoxon and Covariance.

Results: There was an increased in attitude score $(20.9 \pm 3.52)$, carbohydrate intake percentage $(3.7 \pm 7.30 \%)$ and physical activity level $(0.04 \pm 0.01)$ in the treatment group. The energy adequacy level $(-3.4 \pm 13.26 \%)$ and BMI z-score (-0.57 \pm 0.26$)$ decreased in the treatment group. There were difference between the treatment and control groups in attitude, energy adequacy level, physical activity level and BMI z-score after intervention ( $p<0.05)$.

Conclusion: Health education for mothers affect the positive change in mother attitude in terms of the overweight children treatment and increased physical activity level, decreased energy adequacy level and BMI z-score in overweight children.
\end{abstract}

Keywords: Health education, overweight, attitude, energy adequacy level, physical activity level, BMI z-score.

\section{ABSTRAK}

Latar belakang: Persentase anak kelebihan berat badan (overweight) di Propinsi Bengkulu (16,4\%) lebih tinggi daripada nasional (11,9\%). Faktor penyebab overweight adalah asupan energi yang tinggi dan rendahnya aktivitas fisik.

Tujuan penelitian: Menganalisis pengaruh pendidikan kesehatan bagi ibu terhadap perubahan perilaku ibu serta asupan energi, tingkat aktivitas fisik dan skor-z Indeks Massa Tubuh (IMT) pada anak overweight usia 3-6 tahun.

Metode: Desain penelitian quasi-Experiment with non-randomized pre-post test control group. Subjek (48 ibu) diambil secara purposive sampling dan dibagi dalam 2 kelompok (perlakuan dan kontrol). Pendidikan kesehatan pada kelompok perlakuan dilakukan 6 kali dalam 12 minggu. Analisis statistik yang digunakan adalah Independent t-test, Mann Whitney, Paired t-test, Wilcoxon dan Kovarian.

Hasil penelitian: Terdapat peningkatan skor sikap (20,9 $\pm 3,52)$, persentase asupan karbohidrat (3,7 $\pm 7,30 \%)$ dan tingkat aktivitas fisik (0,04 \pm 0,01) pada kelompok perlakuan. Terdapat penurunan tingkat kecukupan energi (-3,4 $\pm 13,26 \%)$ dan skor-z IMT (-0,57 $\pm 0,26)$ pada kelompok perlakuan. Terdapat perbedaan sikap, tingkat kecukupan energi, tingkat aktivitas fisik dan skor-z IMT antara kelompok perlakuan dan kelompok kontrol setelah intervensi $(p<0,05)$.

Simpulan : Pendidikan kesehatan bagi ibu memberikan perubahan sikap yang positif pada ibu dan meningkatkan aktivitas fisik, serta menurunkan asupan energi dan skor-z IMT pada anak overweight.

Kata kunci: Pendidikan kesehatan, overweight, sikap, asupan energi, aktivitas fisik, skor-z IMT.

\section{PENDAHULUAN}

Kelebihan berat badan yang terdiri dari overweight dan obesitas merupakan definisi yang digunakan untuk menggambarkan kelebihan lemak tubuh. ${ }^{1,2}$ Masa prasekolah (usia 3-6 tahun) merupakan masa yang kritis bagi kondisi kelebihan berat badan di usia dewasa. Pada tahun pertama kehidupan, Indeks Massa Tubuh (IMT) meningkat dengan pesat dan bayi memiliki sel adiposa (sel lemak) dalam jumlah yang besar. Sel ini akan menetap jumlahnya antara usia 3 sampai 6 tahun, namun kembali meningkat tajam setelah itu (adipose rebound). Apabila pembentukan

\footnotetext{
1. Poltekkes Kemenkes Bengkulu

2. Fakultas Kedokteran UNDIP Semarang
}

jaringan lemak (adipose rebound) telah terjadi pada usia 3 hingga 6 tahun maka anak memiliki kecenderungan mengalami kelebihan berat badan saat tumbuh dewasa. ${ }^{3}$

Persentase kelebihan berat badan anak di dunia meningkat dari 4,2\% pada tahun 1990 menjadi 6,7\% pada tahun 2010 dan diperkirakan akan mencapai 9,1\% pada tahun 2020. ${ }^{4}$ Persentase anak menderita kelebihan berat badan di Propinsi Bengkulu mengalami peningkatan yaitu $15,5 \%$ pada tahun 2010 menjadi $16,4 \%$ pada tahun 2013 dan persentase tersebut berada di atas persentase nasional $(11,9 \%))^{5,6}$ Penyebab utama kelebihan berat badan pada anak adalah asupan energi yang tinggi dan aktivitas fisik yang kurang. ${ }^{7,8}$ Asupan energi adalah satu sisi dari keseimbangan energi, sehingga faktor makanan adalah faktor yang jelas 
sebagai risiko kelebihan berat badan. ${ }^{9}$ Meningkatkan aktivitas fisik merupakan kunci dalam pengobatan individu yang mengalami kelebihan berat badan. ${ }^{10,11}$

Mencegah dan mengendalikan kelebihan berat badan anak membutuhkan program dan kebijakan beragam serta keterlibatan orangtua yang memiliki peran penting. ${ }^{12}$ Salah satu cara untuk menanggulangi masalah kelebihan berat badan anak adalah dengan melaksanakan pendidikan kesehatan bagi orang tua. ${ }^{13-}$ 15 Pendidikan kesehatan merupakan suatu proses terstruktur sebagai bentuk intervensi utama terhadap perilaku yang bertujuan untuk mempengaruhi pengetahuan, sikap dan perilaku seseorang sehingga tercapai upaya peningkatan kesehatan. ${ }^{16,17}$

Pendidikan gizi untuk orangtua mendorong perubahan perilaku yang positif dalam pemberian makanan anak. ${ }^{18}$ Orangtua mampu mempromosikan makanan sehat pada anak dan meningkatkan dukungan untuk aktivitas fisik anak. ${ }^{19}$ Orangtua terutama ibu memiliki pengaruh sosial yang sangat besar pada pemilihan makanan yang dilakukan anak mereka. ${ }^{7}$ Pada umumnya anak-anak meniru pola makan kedua orangtuanya dan hanya bersikap pasif menerima hidangan yang disajikan bagi mereka. ${ }^{20}$

Penelitian ini bertujuan untuk menganalisis pengaruh pendidikan kesehatan bagi ibu terhadap perubahan perilaku ibu serta asupan energi, aktivitas fisik dan skor-z IMT pada anak usia 3-6 tahun yang kelebihan berat badan. Variabel dalam penelitian ini adalah tingkat pengetahuan, sikap dan perilaku ibu serta asupan zat gizi (tingkat kecukupan energi, persentase asupan karbohidrat, persentase asupan lemak, persentase asupan lemak jenuh, persentase asupan lemak tidak jenuh, tingkat kecukupan protein, asupan serat), tingkat aktivitas fisik dan skor-z IMT anak dengan variabel perancu adalah usia ibu, tingkat pendidikan ibu dan intervensi media lain. Hasil penelitian ini diharapkan dapat dijadikan acuan atau bahan dalam penanganan kelebihan berat badan pada anak.

\section{BAHAN DAN METODE}

\section{Desain, Waktu dan Tempat}

Desain penelitian adalah quasi-experiment with non-randomized pre-post test control group yang dilaksanakan mulai Januari - April 2014 dan dilakukan di Pendidikan Anak Usia Dini Islam Terpadu (PAUD IT) Auladuna untuk kelompok perlakuan sedangkan kelompok kontrol di Taman Kanak-kanak Islam Terpadu (TKIT) Rabbani Kota Bengkulu.

\section{Subjek Penelitian}

Subjek penelitian adalah ibu yang mempunyai anak kelebihan berat badan berdasarkan skor-z IMT dan anak dari ibu tersebut sebagai unit analisis dengan kriteria inklusi anak tidak menderita penyakit kronis, anak tidak menderita cacat bawaan dan bersedia mengikuti tahapan penelitian dengan menandatangani formulir informed consent. Subjek sejumlah 48 orang diambil secara purposive sampling dan dibagi dalam 2 kelompok (perlakuan dan kontrol). Perhitungan besar sampel minimal dengan menggunakan tingkat kesalahan $(\alpha)=5 \%$, power test $=90 \%$ standar deviasi dari penelitian Sanigorski et al. ${ }^{70}=0,04$ dan antisipasi drop out ditambah $10 \%$ sehingga total minimal subjek penelitian yang dibutuhkan adalah 24 orang untuk masing-masing kelompok.

\section{Intervensi}

Intervensi yang diberikan adalah pendidikan kesehatan bagi ibu. Pada kelompok perlakuan diberikan pendidikan kesehatan sebanyak 6 kali selama 12 minggu dan masing-masing pertemuan selama 60 menit dengan metode diskusi partisipasi serta diberikan booklet yang berisi panduan praktis penanganan kelebihan berat badan anak. Pada kelompok kontrol diberikan ceramah kesehatan sebanyak 1 kali di awal penelitian dalam waktu 60 menit.

\section{Cara Pengumpulan Data}

Data identitas subjek, tingkat pengetahuan, sikap dan perilaku ibu serta intervensi media lain diperoleh melalui wawancara dengan kuesioner terstruktur. Data asupan zat gizi diperoleh dengan menggunakan formulir food record selama 2 hari dalam seminggu tidak berurutan. Data tingkat aktivitas fisik diperoleh dengan pencatatan kegiatan sehari dengan menggunakan formulir record aktivitas fisik selama 7 x 24 jam. Data skor-z IMT diperoleh dari pengukuran berat badan dan tinggi badan serta diolah menggunakan program WHO Anthro.

\section{Pengolahan dan Analisis Data}

Data dianalisis dengan menggunakan uji Paired t-test dan Independent t-test. Uji kovarian dilakukan untuk mengetahui efektifitas intervensi yang diberikan.

\section{HASIL}

\section{Karakteristik Subjek}

Subjek yang diteliti sebanyak 48 ibu dengan usia antara 27-37 tahun. Tabel 1 menunjukkan tidak ada perbedaan yang bermakna secara statistik pada usia ibu, tingkat pendidikan ibu dan intervensi media lain pada kelompok perlakuan dibandingkan kelompok kontrol $(p>0,05)$. 
Tabel 1. Deskripsi Karakteristik Subjek Penelitian pada Kelompok Perlakuan dan Kelompok Kontrol di Awal Penelitian

\begin{tabular}{|c|c|c|c|c|c|c|c|}
\hline \multirow{2}{*}{$\begin{array}{l}\text { Karakteristik } \\
\text { Subjek }\end{array}$} & \multicolumn{3}{|c|}{ Perlakuan } & \multicolumn{3}{|c|}{ Kontrol } & \multirow[b]{2}{*}{$p$} \\
\hline & Min & Max & Rerata \pm SD & Min & Max & Rerata \pm SD & \\
\hline Usia ibu (tahun) & 27 & 36 & $30,9 \pm 2,72$ & 27 & 37 & $31,0 \pm 2,62$ & $0,872^{\mathrm{a}}$ \\
\hline Tingkat & 15 & 18 & $16,0 \pm 0,55$ & 12 & 18 & $16,0 \pm 0,96$ & $0,962^{\mathrm{b}}$ \\
\hline $\begin{array}{l}\text { (tahun) } \\
\text { Intervensi media } \\
\text { lain }\end{array}$ & 1,0 & 2,0 & $1,0 \pm 0,38$ & 1,0 & 2,0 & $1,0 \pm 0,33$ & $0,686^{\mathrm{b}}$ \\
\hline
\end{tabular}

Tabel 2. Perbedaan Perilaku Ibu serta Asupan Zat Gizi, Tingkat Aktivitas Fisik dan Skor-z IMT Anak Sebelum dan Setelah Intervensi pada Kelompok Perlakuan dan Kelompok Kontrol

\begin{tabular}{|c|c|c|c|c|c|c|c|}
\hline \multirow{2}{*}{ Variabel } & \multicolumn{3}{|c|}{ Perlakuan } & \multicolumn{3}{|c|}{ Kontrol } & \multirow[b]{2}{*}{$p$} \\
\hline & Min & Max & Rerata \pm SD & Min & Max & Rerata \pm SD & \\
\hline $\begin{array}{l}\text { Tingkat pengetahuan ibu: } \\
-\quad \text { Sebelum perlakuan } \\
-\quad \text { Setelah } 12 \text { minggu } \\
P\end{array}$ & $\begin{array}{l}53,85 \\
84,62\end{array}$ & $\begin{array}{l}84,62 \\
100,0\end{array}$ & $\begin{array}{l}67,3 \pm 8,25 \\
100 \pm 5,07 \\
0,001^{\mathrm{d}}\end{array}$ & $\begin{array}{l}53,85 \\
61,54\end{array}$ & $\begin{array}{l}84,62 \\
84,62\end{array}$ & $\begin{array}{l}69,2 \pm 8,85 \\
73,0 \pm 8,48 \\
0,148^{\mathrm{d}}\end{array}$ & $\begin{array}{l}0,117^{b} \\
0,001^{b}\end{array}$ \\
\hline $\begin{array}{l}\text { Sikap ibu : } \\
-\quad \text { Sebelum perlakuan } \\
-\quad \text { Setelah } 12 \text { minggu } \\
P\end{array}$ & $\begin{array}{l}65,0 \\
87,5\end{array}$ & $\begin{array}{l}77,5 \\
97,5\end{array}$ & $\begin{array}{l}72,5 \pm 3,44 \\
92,5 \pm 3,03 \\
0,001^{\mathrm{d}}\end{array}$ & $\begin{array}{l}65,0 \\
60,0\end{array}$ & $\begin{array}{l}75,0 \\
77,5\end{array}$ & $\begin{array}{l}71,2 \pm 3,29 \\
72,5 \pm 4,85 \\
0,204^{\mathrm{d}}\end{array}$ & $\begin{array}{l}0,791^{b} \\
0,001^{b}\end{array}$ \\
\hline $\begin{array}{l}\text { Perilaku ibu : } \\
-\quad \text { Sebelum perlakuan } \\
-\quad \text { Setelah } 12 \text { minggu } \\
P\end{array}$ & $\begin{array}{l}57,5 \\
87,5\end{array}$ & $\begin{array}{l}77,5 \\
97,5\end{array}$ & $\begin{array}{l}64,3 \pm 2,97 \\
92,5 \pm 3,03 \\
0,001^{\mathrm{c}}\end{array}$ & $\begin{array}{l}60,0 \\
62,5\end{array}$ & $\begin{array}{l}70,0 \\
70,0\end{array}$ & $\begin{array}{l}65,0 \pm 2,75 \\
67,5 \pm 2,44 \\
0,216^{\mathrm{d}}\end{array}$ & $\begin{array}{l}0,142^{b} \\
0,001^{b}\end{array}$ \\
\hline $\begin{array}{l}\text { Tingkat Kecukupan Energi : } \\
-\quad \text { Sebelum perlakuan } \\
-\quad \text { Setelah } 12 \text { minggu } \\
P \\
\end{array}$ & $\begin{array}{l}101,4 \\
95,1\end{array}$ & $\begin{array}{l}158,5 \\
124,6\end{array}$ & $\begin{array}{l}112,8 \pm 14,28 \\
108,0 \pm 7,31 \\
0,001^{\mathrm{d}}\end{array}$ & $\begin{array}{l}95,1 \\
101,4\end{array}$ & $\begin{array}{l}128,3 \\
158,5\end{array}$ & $\begin{array}{l}114,0 \pm 9,3 \\
119,0 \pm 13,19 \\
0,045^{\mathrm{d}}\end{array}$ & $\begin{array}{l}0,951^{b} \\
0,001^{b}\end{array}$ \\
\hline $\begin{array}{l}\text { Persentase asupan karbohidrat: } \\
-\quad \text { Sebelum perlakuan } \\
-\quad \text { Setelah } 12 \text { minggu } \\
P\end{array}$ & $\begin{array}{l}37,8 \\
46,6\end{array}$ & $\begin{array}{l}60,5 \\
65,9\end{array}$ & $\begin{array}{l}50,6 \pm 5,41 \\
54,3 \pm 4,05 \\
0,022^{\mathrm{c}}\end{array}$ & $\begin{array}{l}41,4 \\
42,4\end{array}$ & $\begin{array}{l}68,9 \\
71,5\end{array}$ & $\begin{array}{l}54,0 \pm 6,4 \\
50,7 \pm 6,34 \\
0,230^{\mathrm{d}}\end{array}$ & $\begin{array}{l}0,053^{\mathrm{a}} \\
0,014^{\mathrm{b}}\end{array}$ \\
\hline $\begin{array}{ll}\text { Persentase asupan lemak: } \\
-\quad \text { Sebelum perlakuan } \\
-\quad & \text { Setelah } 12 \text { minggu } \\
P\end{array}$ & $\begin{array}{l}21,5 \\
20,2\end{array}$ & $\begin{array}{l}44,6 \\
38,1\end{array}$ & $\begin{array}{l}32,9 \pm 5,1 \\
30,5 \pm 4,97 \\
0,085^{\mathrm{c}}\end{array}$ & $\begin{array}{l}20,2 \\
19,1\end{array}$ & $\begin{array}{l}44,1 \\
42,3\end{array}$ & $\begin{array}{l}31,2 \pm 5,94 \\
32,0 \pm 5,23 \\
0,637^{\mathrm{c}}\end{array}$ & $\begin{array}{l}0,285^{\mathrm{a}} \\
0,302^{\mathrm{a}}\end{array}$ \\
\hline $\begin{array}{l}\text { Persentase asupan lemak jenuh : } \\
-\quad \text { Sebelum perlakuan } \\
-\quad \text { Setelah } 12 \text { minggu } \\
P \\
\end{array}$ & $\begin{array}{l}31,9 \\
31,2\end{array}$ & $\begin{array}{l}52,3 \\
43,4\end{array}$ & $\begin{array}{l}41,1 \pm 5,77 \\
35,7 \pm 3,23 \\
0,001^{\mathrm{c}}\end{array}$ & $\begin{array}{l}19,1 \\
34,2\end{array}$ & $\begin{array}{l}49,6 \\
58,1\end{array}$ & $\begin{array}{l}40,5 \pm 6,47 \\
45,0 \pm 6,33 \\
0,016^{\mathrm{d}}\end{array}$ & $\begin{array}{l}0,853^{\mathrm{b}} \\
0,001^{\mathrm{a}}\end{array}$ \\
\hline $\begin{array}{l}\text { Persentase asupan lemak tidak jenuh : } \\
-\quad \text { Sebelum perlakuan } \\
-\quad \text { Setelah } 12 \text { minggu } \\
P \\
\end{array}$ & $\begin{array}{l}43,1 \\
52,3\end{array}$ & $\begin{array}{l}62,7 \\
65,6\end{array}$ & $\begin{array}{l}52,7 \pm 4,96 \\
59,4 \pm 4,24 \\
0,001^{\mathrm{c}}\end{array}$ & $\begin{array}{l}42,6 \\
34,1\end{array}$ & $\begin{array}{l}64,4 \\
61,3\end{array}$ & $\begin{array}{l}52,9 \pm 4,61 \\
49,4 \pm 6,74 \\
0,033^{c}\end{array}$ & $\begin{array}{l}0,936^{\mathrm{a}} \\
0,001^{\mathrm{a}}\end{array}$ \\
\hline $\begin{array}{l}\text { Tingkat Kecukupan Protein : } \\
-\quad \text { Sebelum perlakuan } \\
-\quad \text { Setelah } 12 \text { minggu } \\
P\end{array}$ & $\begin{array}{l}89,1 \\
100,1\end{array}$ & $\begin{array}{l}220,7 \\
138,4\end{array}$ & $\begin{array}{l}138,1 \pm 31,75 \\
17,1 \pm 9,75 \\
0,009^{c}\end{array}$ & $\begin{array}{l}106,4 \\
89,1\end{array}$ & $\begin{array}{l}159,4 \\
220,7\end{array}$ & $\begin{array}{l}131,4 \pm 16,41 \\
138,1 \pm 33,30 \\
0,418^{\mathrm{c}}\end{array}$ & $\begin{array}{l}0,366^{\mathrm{a}} \\
0,006^{\mathrm{a}}\end{array}$ \\
\hline $\begin{array}{l}\text { Asupan serat : } \\
-\quad \text { Sebelum perlakuan } \\
-\quad \text { Setelah } 12 \text { minggu } \\
P\end{array}$ & $\begin{array}{l}6,6 \\
9,5\end{array}$ & $\begin{array}{l}12,6 \\
15,2\end{array}$ & $\begin{array}{l}9,3 \pm 1,8 \\
12,3 \pm 1,81 \\
0,001^{\mathrm{c}}\end{array}$ & $\begin{array}{l}6,3 \\
7,4\end{array}$ & $\begin{array}{l}12,2 \\
12,6\end{array}$ & $\begin{array}{l}9,1 \pm 1,3 \\
9,9 \pm 1,73 \\
0,077^{\mathrm{c}}\end{array}$ & $\begin{array}{l}0,591^{\mathrm{a}} \\
0,001^{\mathrm{a}}\end{array}$ \\
\hline
\end{tabular}




\begin{tabular}{|c|c|c|c|c|c|c|c|}
\hline $\begin{array}{ll}- & \text { Sebelum perlakuan } \\
- & \text { Setelah } 12 \text { minggu } \\
P\end{array}$ & $\begin{array}{l}1,31 \\
1,35\end{array}$ & $\begin{array}{l}1,66 \\
1,69\end{array}$ & $\begin{array}{l}1,40 \pm 0,09 \\
1,50 \pm 0,09 \\
0,001^{\mathrm{c}}\end{array}$ & $\begin{array}{l}1,31 \\
1,30\end{array}$ & $\begin{array}{l}1,69 \\
1,68\end{array}$ & $\begin{array}{l}1,47 \pm 0,09 \\
1,40 \pm 0,94 \\
0,001^{\mathrm{c}}\end{array}$ & $\begin{array}{l}0,779^{\mathrm{a}} \\
0,017^{\mathrm{a}}\end{array}$ \\
\hline $\begin{array}{ll}\text { Skor-z IMT anak : } \\
-\quad & \text { Sebelum perlakuan } \\
- & \text { Setelah } 12 \text { minggu } \\
& P\end{array}$ & $\begin{array}{l}2,45 \\
1,99\end{array}$ & $\begin{array}{l}3,58 \\
2,91\end{array}$ & $\begin{array}{l}2,90 \pm 0,29 \\
2,32 \pm 0,28 \\
0,001^{\mathrm{c}}\end{array}$ & $\begin{array}{l}2,36 \\
2,32\end{array}$ & $\begin{array}{l}3,23 \\
3,18\end{array}$ & $\begin{array}{l}2.79 \pm 0,18 \\
2,84 \pm 0.18 \\
0,001^{\mathrm{c}}\end{array}$ & $\begin{array}{l}0,152^{\mathrm{a}} \\
0,001^{\mathrm{a}}\end{array}$ \\
\hline
\end{tabular}

${ }^{a}$ Independent t-test $\quad{ }^{b}$ Mann Whitney

${ }^{c}$ Paired t-test

${ }^{d}$ Wilcoxon

Perbedaan Perilaku Ibu serta Asupan Zat Gizi, Tingkat Aktivitas Fisik dan Skor-z IMT Anak Sebelum dan Setelah Intervensi pada Kelompok Perlakuan dan Kelompok Kontrol

Tabel 2 menunjukkan tidak terdapat perbedaan yang bermakna secara statistik pada tingkat pengetahuan, sikap dan perilaku ibu serta asupan zat gizi, tingkat aktivitas fisik dan skor-z IMT anak pada kelompok perlakuan dan kelompok kontrol di awal penelitian $(p>0,05)$. Setelah dilakukan intervensi selama 12 minggu maka terdapat perbedaan yang bermakna secara statistik pada tingkat pengetahuan, sikap dan perilaku ibu serta tingkat kecukupan energi, persentase asupan karbohidrat, persentase asupan lemak jenuh, persentase asupan lemak tidak jenuh, tingkat kecukupan protein, asupan serat dan tingkat aktivitas fisik pada kelompok perlakuan dibandingkan kelompok kontrol.

Terdapat perbedaan yang bermakna secara statistik pada tingkat pengetahuan, sikap dan perilaku ibu serta tingkat kecukupan energi, persentase asupan karbohidrat, persentase asupan lemak jenuh, persentase asupan lemak tidak jenuh, tingkat kecukupan protein, asupan serat, tingkat aktivitas fisik dan skor-z IMT anak sebelum dan setelah pemberian pendidikan kesehatan bagi ibu pada kelompok perlakuan.

\section{Pengaruh Intervensi terhadap Perubahan Perilaku Ibu serta Asupan Zat Gizi, Tingkat Aktivitas Fisik dan Skor-z IMT Anak}

Tabel 3 menunjukkan terdapat perbedaan yang bermakna secara statistik pada perubahan skor tingkat pengetahuan, sikap dan perilaku ibu serta tingkat kecukupan energi, persentase asupan lemak jenuh, persentase asupan lemak tidak jenuh, tingkat kecukupan protein, tingkat aktivitas fisik dan skor-z IMT anak pada kelompok perlakuan dibandingkan kelompok kontrol $(p<0,05)$.

Tabel 3. Perubahan Skor Perilaku Ibu serta Asupan Zat Gizi, Tingkat Aktivitas Fisik dan Skor-z IMT Anak pada Kelompok Perlakuan dan Kelompok Kontrol

\begin{tabular}{|c|c|c|c|c|c|c|c|}
\hline \multirow{2}{*}{ Variabel } & \multicolumn{3}{|c|}{ Perlakuan } & \multicolumn{3}{|c|}{ Kontrol } & \multirow[b]{2}{*}{$p$} \\
\hline & Min & Max & Rerata \pm SD & Min & Max & Rerata \pm SD & \\
\hline $\begin{array}{l}\Delta \text { Tingkat pengetahuan } \\
\text { ibu }\end{array}$ & 3,8 & 84,6 & $67,3 \pm 8,25$ & $-23,1$ & 23,1 & $2,8 \pm 11,02$ & $0,001^{\mathrm{a}}$ \\
\hline$\Delta$ Sikap ibu & 12,5 & 30,0 & $20,9 \pm 3,52$ & $-15,0$ & 10,0 & $2,5 \pm 5,61$ & $0,001^{\mathrm{b}}$ \\
\hline$\Delta$ Perilaku ibu & $-5,0$ & 30 & $9,7 \pm 10,59$ & $-5,0$ & 5,0 & $0,0 \pm 3,08$ & $0,001^{\mathrm{b}}$ \\
\hline $\begin{array}{l}\Delta \text { Tingkat Kecukupan } \\
\text { Energi }\end{array}$ & $-45,9$ & 4,0 & $-3,4 \pm 13,26$ & $-2,6$ & 49,9 & $1,4 \pm 13,23$ & $0,001^{\mathrm{b}}$ \\
\hline $\begin{array}{l}\Delta \text { Persentase asupan } \\
\text { karbohidrat }\end{array}$ & $-10,2$ & 21,2 & $3,6 \pm 7,30$ & $-21,7$ & 23,6 & $0,1 \pm 10,67$ & $0,196^{\mathrm{a}}$ \\
\hline $\begin{array}{l}\Delta \text { Persentase asupan } \\
\text { lemak }\end{array}$ & $-17,1$ & 9,4 & $-2,4 \pm 6,67$ & $-13,5$ & 13,9 & $0,7 \pm 8,09$ & $0,138^{\mathrm{a}}$ \\
\hline $\begin{array}{l}\Delta \text { Persentase asupan } \\
\text { lemak jenuh }\end{array}$ & $-17,3$ & 3,8 & $-5,2 \pm 5,51$ & $-10,1$ & 23,0 & $4,6 \pm 8,97$ & $0,001^{\mathrm{a}}$ \\
\hline $\begin{array}{l}\Delta \text { Persentase asupan } \\
\text { lemak tidak jenuh }\end{array}$ & $-4,2$ & 19,2 & $6,6 \pm 5,60$ & $-18,6$ & 7,9 & $-1,1 \pm 8,02$ & $0,001^{\mathrm{a}}$ \\
\hline $\begin{array}{l}\Delta \text { Tingkat Kecukupan } \\
\text { Protein }\end{array}$ & $-102,3$ & 39,1 & $-22,8 \pm 34,51$ & $-64,9$ & 88,2 & $7,2 \pm 39,68$ & $0,007^{\mathrm{a}}$ \\
\hline$\Delta$ Asupan serat & $-7,6$ & 5,3 & $-0,1 \pm 3,09$ & $-5,1$ & 7,6 & $1,1 \pm 3,58$ & $0,191^{\mathrm{a}}$ \\
\hline $\begin{array}{l}\Delta \text { Tingkat aktivitas } \\
\text { fisik }\end{array}$ & 0,01 & 0,07 & $0,04 \pm 0,01$ & $-0,05$ & 0,03 & $-0,01 \pm 0,01$ & $0,001^{\mathrm{b}}$ \\
\hline$\Delta$ Skor-z IMT anak & $-1,51$ & $-0,05$ & $-0,57 \pm 0,26$ & $-0,05$ & 0,18 & $0,05 \pm 0,06$ & $0,001^{\mathrm{b}}$ \\
\hline
\end{tabular}


Untuk menguji efektifitas perlakuan yang diberikan dimana diharapkan pada kelompok perlakuan memiliki perubahan terkait perlakuan yang diberikan dibanding dengan kelompok kontrol maka dilakukan uji kovarian. Setelah melalui pengujian syarat variabel untuk dapat dilanjutkan ke uji kovarian maka variabel yang memenuhi syarat adalah sikap ibu, tingkat kecukupan energi, persentase asupan karbohidrat, tingkat aktivitas fisik dan skor-z IMT anak. Tabel 4 menunjukkan terdapat perbedaan hasil akhir pada variabel sikap ibu, tingkat kecukupan energi, tingkat aktivitas fisik dan skor-z IMT anak antara kelompok perlakuan dan kelompok kontrol setelah diberikan intervensi $(p<$ $0,05)$.

Tabel 4. Model Akhir Analisis Kovarian

\begin{tabular}{|c|c|c|c|c|c|}
\hline \multirow{2}{*}{ Variabel } & \multicolumn{2}{|l|}{ Kelompok } & \multirow{2}{*}{$\mathrm{F}$} & \multirow{2}{*}{$p^{\mathfrak{f}}$} & \multirow{2}{*}{$\begin{array}{l}\text { Partial Eta } \\
\text { squared }\end{array}$} \\
\hline & Perlakuan & Kontrol & & & \\
\hline Sikap ibu & $92,5 \pm 3,03$ & $72,1 \pm 4,85$ & 306,374 & 0,001 & 0,872 \\
\hline Tingkat kecukupan energi & $108,1 \pm 7,30$ & $119,1 \pm 13,2$ & 15,580 & 0,001 & 0,257 \\
\hline Persentase asupan karbohidrat & $54,3 \pm 4,05$ & $51,4 \pm 6,34$ & 1,714 & 0,197 & 0,037 \\
\hline Tingkat aktivitas fisik & $1,5 \pm 0,09$ & $1,4 \pm 0,09$ & 200,091 & 0,001 & 0,816 \\
\hline Skor-z IMT & $2,32 \pm 0,28$ & $2,84 \pm 0,18$ & 132,393 & 0,001 & 0,746 \\
\hline
\end{tabular}

General Linear Model dikontrol oleh hasil pemeriksaan awal masing-masing variabel.

\section{PEMBAHASAN}

Terjadi perubahan sikap ibu ke arah positif mengenai penanganan kelebihan berat badan anak pada kelompok perlakuan dibandingkan kelompok kontrol setelah diberikan intervensi. Sikap merupakan salah satu tahapan menuju proses perubahan perilaku, dengan adanya perubahan sikap yang positif diharapkan akan terjadi perubahan perilaku dari subjek sesuai dengan yang diharapkan. ${ }^{21}$

Penyebab mendasar dari kelebihan berat badan adalah ketidakseimbangan energi antara kalori yang dikonsumsi di satu sisi, dan kalori yang dikeluarkan di sisi lain. ${ }^{22}$ Terdapat perbedaan tingkat kecukupan energi pada kelompok perlakuan dibandingkan kelompok kontrol setelah intervensi dengan rerata tingkat kecukupan energi lebih tinggi pada kelompok kontrol dibandingkan kelompok perlakuan. Hal ini berarti bahwa pendidikan kesehatan bagi ibu dapat menurunkan tingkat kecukupan energi anak pada kelompok perlakuan. Hal ini sejalan dengan penelitian yang dilakukan Tandon PS et al dan Davison KK et al yang menyimpulkan bahwa intervensi pendidikan kesehatan pada orangtua dapat menurunkan asupan energi anak. ${ }^{19,23}$

Aktivitas fisik adalah penentu utama pengeluaran energi, dan dengan demikian merupakan dasar untuk keseimbangan energi dan mengontrol berat badan. ${ }^{24}$ Setelah dilakukan intervensi maka terdapat perbedaan tingkat aktivitas fisik antara kelompok perlakuan dan kelompok kontrol dengan rerata tingkat aktivitas fisik lebih tinggi pada kelompok perlakuan dibandingkan kelompok kontrol. Hal ini berarti bahwa pendidikan kesehatan bagi ibu dapat meningkatkan aktivitas fisik anak di kelompok perlakuan. Hal ini sejalan dengan penelitian Reilly $\mathrm{JJ}$ et al yang menunjukkan intervensi pendidikan kesehatan memberikan pengaruh yang signifikan pada peningkatan aktivitas fisik anak. ${ }^{3}$ Penelitian Boles RE et al membandingkan aktivitas fisik anak usia prasekolah yang kelebihan berat badan dan anak yang tidak kelebihan berat badan dan menyimpulkan bahwa ada hubungan yang signifikan antara aktivitas fisik yang kurang dengan kelebihan berat badan anak dan keluarga yang memiliki anak kelebihan berat badan mempunyai perilaku meletakkan televisi di kamar tidur anak..$^{25}$

Klasifikasi internasional untuk derajat kelebihan berat badan didasarkan pada Indeks Massa Tubuh (IMT). ${ }^{7}$ IMT sering digunakan untuk menilai status gizi karena relatif mudah untuk mengukur dan berkorelasi dengan lemak tubuh. ${ }^{26}$ IMT bervariasi menurut usia dan jenis kelamin, karena itu IMT memiliki ambang batas tertentu sesuai dengan usia dan jenis kelamin. ${ }^{9}$ Klasifikasi status gizi anak berdasarkan IMT ditentukan dengan menggunakan skor-z. ${ }^{27}$ Terdapat perbedaan skor-z IMT pada kelompok perlakuan dibandingkan kelompok kontrol setelah intervensi dengan rerata skor-z IMT lebih tinggi pada kelompok kontrol dibandingkan kelompok perlakuan. Hal ini berarti bahwa pendidikan kesehatan bagi ibu dapat menurunkan skor-z IMT anak pada kelompok perlakuan. Hal ini sejalan dengan beberapa penelitian yang memberikan intervensi berupa pendidikan kesehatan bagi orangtua dan menganalisis pengaruhnya pada skor-z IMT anak yang disimpulkan bahwa pendidikan kesehatan dapat menurunkan skor-z IMT anak. ${ }^{28-31}$

Hasil pengujian efektifitas pemberian pendidikan kesehatan bagi ibu terhadap perubahan variabel-variabel yang diteliti didapatkan bahwa sumbangan efektif pemberian pendidikan kesehatan bagi ibu terhadap perubahan hasil pada masing-masing variabel yakni $87,2 \%$ untuk sikap ibu; $25,7 \%$ untuk 
tingkat kecukupan energi; $81,6 \%$ untuk tingkat aktivitas fisik dan 74,6\% untuk skor-z IMT.

\section{SIMPULAN}

Berdasarkan hasil penelitian disimpulkan bahwa pendidikan kesehatan bagi ibu dapat memberikan perubahan sikap yang positif pada ibu dalam hal penanganan kelebihan berat badan anak dan dapat meningkatkan aktivitas fisik serta menurunkan tingkat kecukupan energi dan skor-z IMT pada anak yang kelebihan berat badan.

\section{DAFTAR PUSTAKA}

1. Bray GA, Ryan DH. Overweight and the Metabolic Syndrome (From Bench to Bedside). USA : Springer : 2006.

2. Direktorat Jenderal Bina Gizi dan Kesehatan Ibu dan Anak. Pedoman Pencegahan dan Penanggulangan Kegemukan dan Obesitas pada Anak Sekolah. Jakarta : Kementerian Kesehatan RI : 2012.

3. Reilly JJ. Physical Activity, Sedentary Behaviour and Energy Balance in the Preschool Child: Opportunities for Early Obesity Prevention, Symposium on 'Behavioural Nutrition and Energy Balance in the Young'. Proceedings of the Nutrition Society (2008), 67, 317-325.

4. Onis M, Blossner M, Borghi E. Global Prevalence and Trends of Overweight and Obesity among Preschool Children. Am J Clin Nutr 2010;92:1257-64.

5. Badan Penelitian dan Pengembangan Kesehatan Kementerian Kesehatan RI. Riset Kesehatan Dasar RISKESDAS 2013. Kemenkes RI; 2013.

6. Badan Penelitian dan Pengembangan Kesehatan Kementerian Kesehatan RI. Riset Kesehatan Dasar RISKESDAS 2010. Kemenkes RI; 2010.

7. Gibney MJ, Margetts BM, Kearney JM, Arab L. Gizi Kesehatan Masyarakat (Public Health Nutrition), Hartono A. Penerjemah. Jilid 1 Edisi Bahasa Indonesia. Jakarta: Buku Kedokteran EGC : 2009

8. Wilkinson D and McCargar L. Current Perspective on Preschooler Obesity Prevention. Canadian Council of Food and Nutrition, Canada : 2008 .

9. Lobstein T, Baur L, Uauy R. Obesity in Children and Young People: a Crisis in Public Health. Obesity Reviews 2004, 5 (Suppl. 1), 4-85.

10. Wilkinson D and McCargar L. Prevention of Overweight and Obesity in Young Canadian Children. Canadian Council of Food and Nutrition, Canada ; 2008.
11. Wareham N. Physical activity and obesity prevention. Obesity reviews (2007) 8 (Suppl. 1), 109-114.

12. Lindsay AC, Sussner KM, Kim J, et al. The Role of Parents in Preventing Childhood Obesity. VOL. 16 / NO. 1 / SPRING 2006.

13. Syafiq A, Setiarini A, Utari DM, dkk. Gizi dan Kesehatan Masyarakat. Jakarta: RajaGrafindo Persada; 2012.

14. Kahn RF. Continuing Medical Education in Nutrition. Am J Clin Nutr 2006;83(suppl):981S4S.

15. Prasetyawati AE. Kesehatan Ibu dan Anak (KIA) dalam Millenium Development Goals (MDGs). Yogyakarta: Nuha Medika; 2012.

16. Notoatmodjo S. Kesehatan Masyarakat Ilmu dan Seni. Jakarta: Rineka Cipta; 2007.

17. Notoatmodjo S. Metodologi Penelitian Kesehatan. Jakarta: Rineka Cipta; 2012.

18. Rich K. Parent Nutrition Education and the Influence on Family Lifestyle Behavior Changes. Tesis. Logan : Utah State University : 2012.

19. Davison KK, Jurkowski JM, Li K, et al. A Childhood Obesity Intervention Developed by Families for Families: Results from a Pilot Study. International Journal of Behavioral Nutrition and Physical Activity 2013, 10:3.

20. Wahyu GG. Obesitas pada Anak. Yogyakarta : Bentang Pustaka : 2009.

21. Notoatmodjo S. Pendidikan dan Perilaku Kesehatan. Jakarta : Rineka Cipta : 2007.

22. World Health Organization. Obesity and Overweight. Geneva ; WHO : 2006.

23. Tandon PS, Wright J, Zhou C, et al. Nutrition Menu Labeling May Lead to Lower-Calorie Restaurant Meal Choices for Children. Pediatrics $2010 ; 125 ; 244$.

24. World Health Organization. Global strategy on Diet, Physical Activity and Health. Geneva :WHO : 2004.

25. Boles RE, Scharf C, Filigno SS, et al. Differences in Home Food and Activity Environments between Obese and Healthy Weight Families of Preschool Children. J Nutr Educ Behav. 2013;45:222-231.

26. Nihiser AJ, Lee SM, Wechsler H, et al. Body Mass Index Measurement in Schools. J Sch Health 2007;77:651-671.

27. World Health Organization. WHO Child Growth Standards : Length/Height-for-Age, Weight-forAge, Weight-for-Length, Weight-for-Height and Body Mass Index-for-Age : Methods and Development. Geneva :WHO : 2006.

28. Sanigorski AM, Bell AC, Kremer $\mathrm{Pj}$, et al. Reducing Obesity in Early Childhood: Results From Romp \& Chomp, an Australian Community- 
Wide Intervention Program. Am J Clin Nutr 2010;91:831-40.

29. McLellan KCP, Bianchessi ALV, Rinaldi AE, et al. Improvements of Nutrition Behavior Fitness and Body Fatness with a Short-Term after School Intervention Program. Food and Nutrition Sciences, 2013, 4, 18-24.

30. Sanigorski AM, Bell AC, Kremer $\mathrm{Pj}$, et al. Reducing Unhealthy Weight Gain in Children Through Community Capacity-Building: Results of a Quasiexperimental Intervention Program, Be Active Eat Well. International Journal of Obesity (2008) 32, 1060-1067.

31. Grieken AV, Veldhuis L, Renders CM, et al. Population-Based Childhood Overweight Prevention: Outcomes of the 'Be Active, Eat Right' Study. PLoS ONE 8(5): e65376. doi:10.1371. 